\title{
]AH[The attitudes of recently-arrived Polish migrants to Irish English
}

\author{
]au[CHLOÉ DISKIN* AND VERA REGAN**
}

Jabh[ABSTRACT:_ Jabs[This article presents a case study of eight Polish migrants residing in Dublin, Ireland and examines their language ideologies through an analysis of the metalinguistic discourse surrounding Irish English, world Englishes, and notions of 'standardness' that arose in the course of eight extended interviews in 2012. Adapting Bucholtz and Hall's concept of markedness or 'hierarchical structuring of difference', this study structures the migrants' views towards world Englishes as operating along two axes of markedness and desirability. Overall, the migrants exhibit three broadly differing views of Irish English: positive, negative and ambivalent, and at times explicitly articulate their views in comparison with those of traditional Inner Circle varieties, such as British and American English.

\section{$\circlearrowleft$}

\section{]ha[INTRODUCTION}

]hb[Recent migration to Ireland

]ro[Whereas Jreland was previously known as a country of emigration, it has in recent years become a country of large-scale in-migration. This has been largely attributed to the prosperity and wealth generated during the economic boom or 'Celtic Tiger' years, which attracted many migrant workers to Ireland in the late 1990s and early 2000s (Central Statistics Office 2012). Despite the economic recession that set in after 2008, the number of non-Irish nationals residing in Ireland has continued to increase. In the period 2006-2011 (for which the most recent census data exists) this number increased by 143 per cent (Central Statistics Office 2012: 7), indicating the extent to which migration has become a permanent feature of Ireland's social and demographic profile. This article focuses on migrants from the Polish community, who are the largest non-Irish group in Ireland with a population of 122,585 (Central Statistics Office 2012: 7).

\section{]hb[English in the world}

]ro[English has been described as a 'hypercentral language' and 'the pivot of the world language system'(de Swaan 2010: 57). However, despite a shift towards the recognition of 'localised forms' and 'new Englishes' (Bolton 2003: 1), it could be said that there is a dominant ideology, at least in the Expanding Circle (Kachru 1985), that certain varieties of English are considered to be of more value than others in the 'linguistic marketplace' (Bourdieu 1991). Among English language learners, these tend to be the Inner Circle varieties (Widdowson 1994), particularly British (henceforth BrE) and American English (henceforth AmE), which are considered to be the 'gold standard'. 'These varieties are then propagated as the preferred pedagogical target within instructed settings. The issue has been raised by Matsuda and Matsuda (2010: 370): 'Because English in expanding circle contexts includes a wide array of international and intranational uses, the traditional model of setting a single target variety has become problematic'.

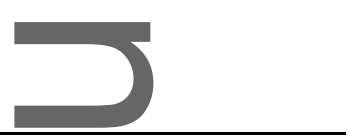

]audet[ [ University College Dublin, UCD Humanities Institute, University College Dublin Belfield, Dublin 4, Ireland. E-mail: chloe.diskin@ucdconnect.ie

** University College Dublin, School of Languages, Cultures and Linguistics, University College

Dublin Belfield, Dublin 4, Ireland. E-mail: vera.regan@ucd.ie

This is the author manuscript accepted for publication and has undergone full peer review but has not been through the copyediting, typesetting, pagination and proofreading process, which may lead to differences between this version and the Version of Record. Please cite this article as doi:

10.1111/weng. 12253 .

This article is protected by copyright. All rights reserved. 


\section{]hb[English language learning in Poland}

]ro[There is no language requirement for Polish (and other European Union) citizens wishing to reside in Ireland, and little is known about their language proficiency upon arrival. However, while older generations in Poland may have learned Russian as a primary foreign language, English has now become the most widely taught foreign language, not just in Poland, but around the globe (Noack \& Gamio 2015). Poland can be considered to be an Expanding Circle country, where English occupies a more 'formal' status in the sense that it is initially primarily taught as a foreign language within the school system.

]p[The participants in this case study had all been exposed to English exclusively within the formal edueation setting, where English was typically taught from textbooks. The English as a Foreign Language (EFL) textbook industry is viewed as 'lagging behind' the movement towards the recognition of world Englishes, where 'the dominance of codified varieties of English is constantly being reified by well-intended teachers and editors' (Matsuda \& Matsuda 2010: 371). BrE and AmE were the dominant varieties to which the participants in this study had been previously exposed, and they were generally unprepared for the majority variety they encountered upon arrival in Ireland: Irish English (henceforth IrE).

\section{]hb [Newcomers and Irish English}

]ro[Comparatively little is known about newcomers to Ireland and their views towards IrE, but both Migge (2012) amd Diskin (2016) report that, on the whole, recently-arrived migrants view it as markedly different from the varieties to which they had previously been exposed. There can also be some ambiguity and contradiction on the part of Irish people themselves in relation to the status of IrE as an implicitly codified standard or supraregional form of speech (Hickey 2012: 102-105). However, it is also an important identity marker: Irish natives have been shown to rate their own variety highly for attractiveness in a process of ingroup loyalty (Coupland \& Bishop 2007: 80). As regards their attitudes towards other Inner Circle varieties, 'native speakers' of IrE tend to avoid emulations both of BrE, for fear of sounding 'snobbish' (Hickey 2012), and AmE, which may appear as an over-affiliation with the language of 'Valley Girls' (Diskin 2016: 308) and American sitcoms such as Friends. This status quo results in a specific and complex site of exposure to and acquisition of the English language for recent arrivals in Ireland, where their ideologies surrounding 'standardness' may come into conflict with the desire to integrate into the local community.

\section{]ha[LANGUAGE ATTITUDES AND IDEOLOGIES}

]ro[Language ideologies are understood in this article as 'a cultural system of ideas about social and linguistic relationships, together with their loading of moral and political interests' (Irvine 1989: 255). They are 'situated beliefs' that are 'mediated on an interactional level' (de Costa 2011: 349), 'expressed through talk about language', and 'refracted in patterns of use as learners negotiate meaning' (Jaffe 2009; Seargeant 2009). Individuals generally tend to delineate varieties that are different from their own, rather than those that are similar to their own, clearly identifying those individuals or groups to which they do not belong (LippiGreen 1994). In a similar vein, Bucholtz and Hall (2004: 383-384) claim that identity is often established through 'adequation', the pursuit of socially-recognised sameness, and 'distinction', the production of salient difference. The present analysis draws on this adequation and distinction model in investigating the extent to which individuals view IrE as more similar or different from their individual perception of what constitutes the 'English language'. The analysis will draw on the concept of markedness or the 'hierarchical

This article is protected by copyright. All rights reserved. 
structuring of difference' (Bucholtz \& Hall 2004: 372), as articulated by the participants in their metalinguistic discourse, and will analyse the extent to which $\operatorname{IrE}$ is viewed as a desirable resource within their repertoire.

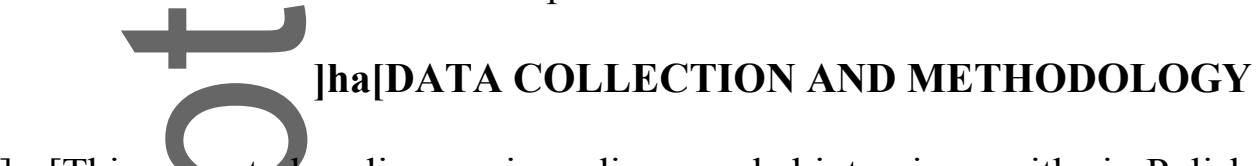

]ro[This case study relies on six audio-recorded interviews with six Polish migrants. It draws on a larger study of 41 migrants and their acquisition of discourse-pragmatic markers (Diskin \& Regan 2015). Following the method of the semi-structured sociolinguistic interview (Labov 1972), the first author conducted these one-on-one interviews throughout 2012. The interviews were either held in public places, such as cafes, or in the participants' own homes.

]p[The question modules mostly concerned the participants' daily lives and interests, but at least one question was designed to elicit language attitudes and ideologies about IrE. It was at times posedidirectly, such as 'Do you think that the way we speak English here is different to the way you learnt English in school?' whereas at other times the topic arose naturally or followed a related question, such as 'Do you remember the first day you arrived in Dublin?' Although the question modules aimed at eliciting the topic of language, they were not designed to impute particular attitudes about language to the participants.

Table 1 gives a breakdown of the participants, in the order in which they are discussed in the present article, and provides their length of residence in Ireland, and their self-reported proficiency in English according to their responses to a questionnaire based on the Common European Framework of Reference for Language (CEFR) (Council of Europe 2001). ${ }^{2}$

$<$ Table 1 near here $>$

]th[Table 1. Participants

\begin{tabular}{|c|c|c|c|c|}
\hline ]tab[Name Sex & Age & $\begin{array}{l}\text { Occupation at time of } \\
\text { interview }\end{array}$ & $\begin{array}{l}\text { Length of } \\
\text { residence in } \\
\text { Ireland (years) }\end{array}$ & $\begin{array}{l}\text { Self-reported } \\
\text { proficiency in } \\
\text { English (CEFR) }\end{array}$ \\
\hline Janusz & 31 & Area sales manager & 6 & C1 (Proficient user) \\
\hline Aleksanc & 36 & $\begin{array}{l}\text { Care assistant in nursing } \\
\text { home }\end{array}$ & 6.5 & $\mathrm{C} 1$ (Proficient user) \\
\hline Elżbieta & 30 & $\begin{array}{l}\text { Maternity leave from } \\
\text { teaching }\end{array}$ & 5 & C1 (Proficient user) \\
\hline Michał & 33 & Project manager & 7 & $\begin{array}{l}\text { B2 (Independent } \\
\text { user) }\end{array}$ \\
\hline Beata & 33 & $\begin{array}{l}\text { Unemployed } \\
\text { (previously barista) }\end{array}$ & 4 & $\begin{array}{l}\text { B1 (Independent } \\
\text { user) }\end{array}$ \\
\hline Dominik & 29 & Print room operator & 4 & $\begin{array}{l}\text { B2 (Independent } \\
\text { user) }\end{array}$ \\
\hline
\end{tabular}

\section{ha[POSITIVE ATTITUDES TOWARDS IRISH ENGLISH}

\section{]hb[Janusz}

]ro[Janusz considers himself to have begun his career in Ireland. He also considers himself to have been very successful, progressing in a short time from his first position as a retail assistant in a newsagent, to his current position as an area sales manager for a large Dublinbased company, where his work involves frequent travel around the country. Throughout his

This article is protected by copyright. All rights reserved. 
interview, he tended to evaluate his positive experience through the lens of his various achievements, and he counted his language proficiency and his ability to communicate with locals as one of his many accomplishments.

]p[In (1) below, Janusz admits that the language he first encountered in Ireland was 'different' (line 12), but that he acquired it rapidly and with relative ease, through his face-toface encounters working at the newsagent (lines 10-11). ${ }^{3}$ This in turn allowed him to learn about the 'behaviours' (line 4) and 'different points of view' (line 15) of his customers - in other words, learning the language helped him to better understand the mentality of those in his new environment.]de[

(1) Janusz

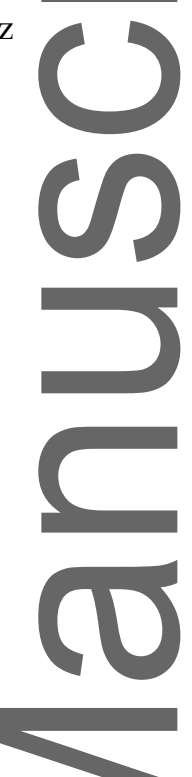

\author{
As in the store you (.) \\ Every day you see different people \\ So you can learn about them very fast \\ Behaviours and (.) \\ The way they say things (..) \\ Operate and so on and so on, so you could just (.) \\ $[\ldots]$ \\ That was just to-to-to give me that kind of um (.) \\ Insight on that \\ And then the-the language as well like you know you (.) \\ You are just behind the counter talking to people all day \\ Different language \\ Every-every-every-everyone's every single person speaks different \\ You know so different language \\ Different-different points of view and so on and so on \\ So can learn from there
}

]fo[Janusz's work brings him to many areas that would be considered rural or even remote by Dubliners, and in (2) below, he prides himself on the fact that he is familiar with places such as Portlaoise and Galway (lines 4-5). ${ }^{4} \mathrm{He}$ remarks on the 'different accents' that are spoken there (line 3 ) and recounts that at the beginning, he could not understand anyone in these areas (line-7). However, these accents have now become 'kind of normal' for him (line 8) and he claims this exposure to varieties of IrE outside of Dublin has led him to say 'things' that the people in his Dublin office cannot understand (line 11). He is incredulous that his coworkers are not familiar with the spectrum of different varieties of IrE outside of Dublin, such as the variety spoken on the opposite side of the country in Mayo (line 18). He considers his knowledge of the range of Irish Englishes to be a positive development (line 21) that allows him to him to 'see what's going on' (line 23), or get under the skin of the Irish, so to speak. He considers this knowledge to be part of his sociolinguistic competence (Bayley \& Regan 2004), and these are skills that he can call upon in everyday encounters related to his profession.]de[

(2) Janusz

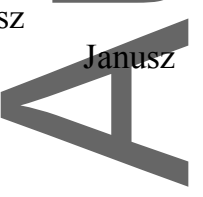

Chloé

Janusz
That was a good time as well

As I travelled a-around the country quite a lot

So I could hear different people (.) different accents

And-and I remember when I started in Portlaoise here at all

Halfway to Galway

Mm.

I couldn't understand a $\mathrm{s}^{* *} \mathrm{t}$ what they talking to me

This article is protected by copyright. All rights reserved. 


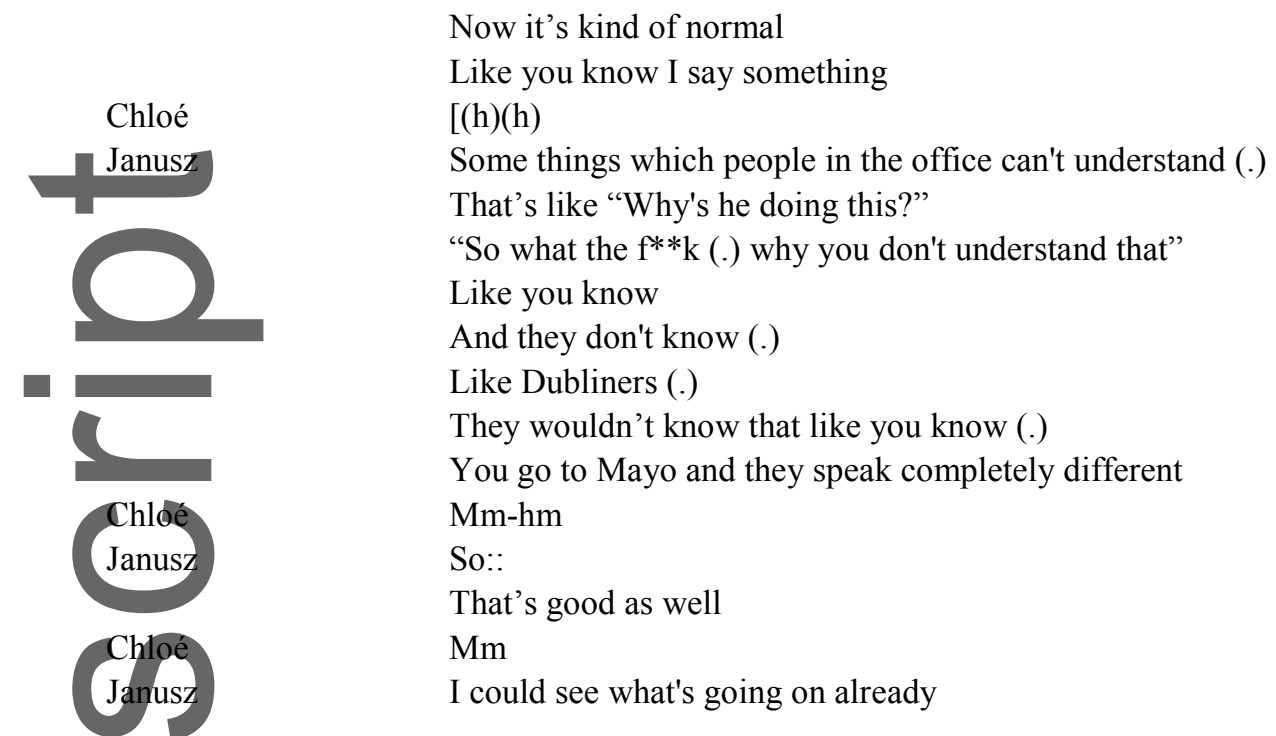

]hb[Aleksander

]ro[Aleksander had been living with his young family in Dublin for six years at the time of interview and, similarly to Janusz, he considers himself to have acquired IrE. However, he is undecided as to whether this acquisition has been conscious or not, and finds that his use of IrE at times comes into conflict with his identity as Polish; although overall, his views towards the variety are positive. In (3) below, Aleksander recounts a story where he was mistaken for an Irishman on a train in Poland. He expresses indignation at this misunderstanding (lines 10-13), and proclaims himself to be wholly Polish: 'from my toes up to my nose!' He states 'I love my accent' (line 35) and describes his Polish-accented English as 'lovely' (line 22). However, there is an element of humour in his storytelling: it seems as though he uses 'lovely' ironically and his tone indicates mock, rather than genuine, indignation. Nonetheless, his playfulness still indicates self-pride and self-worth - he does not feel the need to change his accent or the need to 'pretend' to be Irish. ]de[

(3) Aleksander

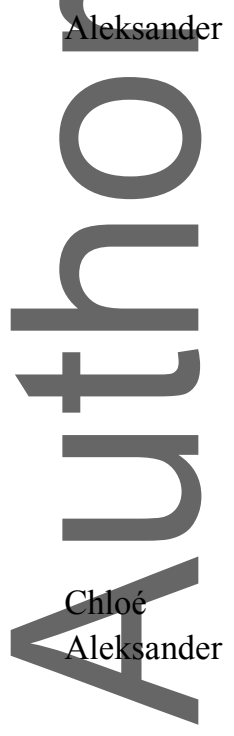

When I was in Poland I was travelling by the train

$[\ldots]$

I went out for a smoke

And there was a guy who had a fear in his eyes passing me

And he was speaking English

I said "Can I help you?"

He said "Oh Jesus (.) yeah I found somebody who speaks English"

[...]

And he said "You Irish!"

I said "I'm not!"

"I'm Polish!"

"From my toes up to my nose!"

You know I-I am Polish

$[(\mathrm{h})(\mathrm{h})(\mathrm{h})$

Uh it's uh "But you- you speak Irish!"

Uh::

The way (.) probably I speak (.)

For-for m-many of my friends (.)

Especially here when somebody says::

We say that I-I-I'm speaking Irish to:: way

This article is protected by copyright. All rights reserved. 


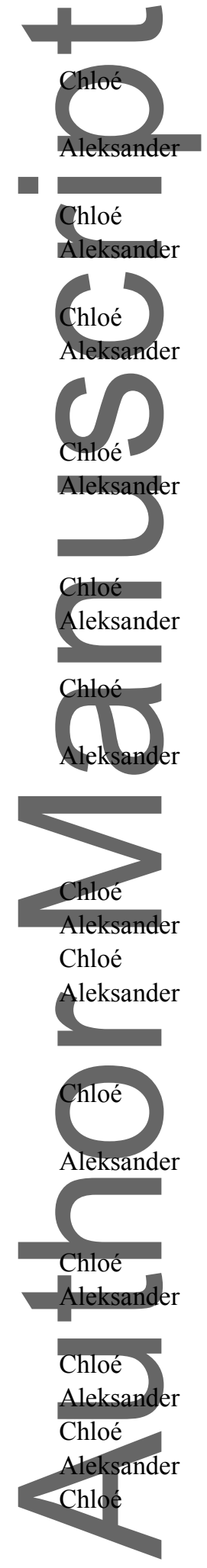

Aleksander Chloé
It's impossible (.) okay

You hear my lovely Polish accent for everything that I'm saying That's-that's natural

I'm proud of it (.) okay

I will not lose it

$\mathrm{Mm}$

$\mathrm{Mm}-\mathrm{hm}$

So even though I'm not even try::

I know the people that they try to lose the Polish accent

Oh yeah?

And that's not funny for me

Uh because that's only ac- a- mm it sounds like acting (.) okay?

$[\mathrm{Mm}$

That you're trying to be somebody else that you're not really are

Um (.) I love my accent

As long as the people can understand it (.) alright?

[Mm

But I-I would

Be able to understand somebody who wants to change his accent

Because his accent is so strong that nobody can understand him

Mm-hm

But to make it more Irish because you're not Irish::

But you can find those people um

[Yeah

Mm-hm

Among the immigrants probably but um

That was the one funny situation

Somebody called me Irish and uh

In Scotland I was called Irish once as well

Yeah?

I dunno (.) maybe

[And:

Maybe not the accent (.)

Maybe the words that I've been using

Like "grand" or whatever

Mm-hm yeah

Yeah

You know?

The way I- all- all my English (.)

I picked it up over here

$\mathrm{Mm}-\mathrm{hm}$

So::

It didn't come from books

Yeah

Or from the schools so:

$\mathrm{Mm}$

This is probably why they-they-they considered me as a common Irish Yeah

And how- how do you take that?

Do you consider it a compliment or:?

Uh it's compliment (.) yeah

Yeah

This article is protected by copyright. All rights reserved. 
]fo[Aleksander refers to 'the immigrants' (line 46) and claims that these would be people likely to put on an Irish accent. Though this statement, he dissociates himself from this grouping, despite the fact that he does not consider himself to be Irish either. The 'immigrants' who wholeheartedly adopt the Irish accent are, from his standpoint, 'acting' (line 32) and trying to be somebody that they're not (line 34). He acknowledges that a foreign accent should be modified in order to make oneself understood (lines 38-40), but that any further modification is a betrayal of one's true cultural roots and origins, and appears inauthentic. Aleksander prides himself on the markedness of his speech: he specifically desires to be regarded as Polish, and uses his accent as a tool to express this. On the other hand, he appears to pride himself on the authenticity of his acquisition of the local vernacular. He claims that he never learned English from books or in school (lines 63-65), which are generally regarded as sources of 'correct' and 'standard' language. He does not refer to BrE or AmE as the anchored varieties within the spectrum of world Englishes, and he also does not aspire towards a particular 'standard' English. He views IrE as marked, but not particularly undesirable.

]p[Aleksander emerged as one of the more ingroup-oriented migrants in this study, and described himself at numerous stages as being 'in the Polish community'. He spends a great proportion of his non-working time as a scout leader with the Polish group within Scouting Ireland and he is proud to have achieved the status and recognition it accords Poles within the organization. However, at other points in his interview he also indicated that he considered himself to be an active member of Irish society - for example, he is an active member of the Parent-Teacher Association at his daughter's primary school in Dublin. Furthermore, in (4) below he makes a point of explaining the difference in being involved with the Polish group within Scouting Jreland, rather than operating as an autonomous grouping: it permits them to simultaneously be a part of and 'assimilate' to Irish culture (line 24), while retaining their Polish identity - a state of identity leading towards hybridity (Bhabha 2004).]de[

(4)

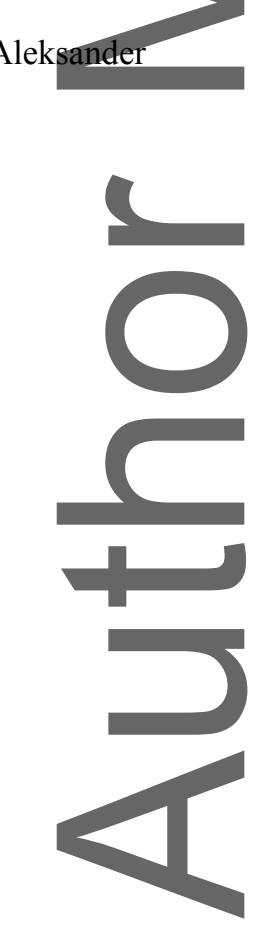

There was an agreement between the

You know between the national office of Scouting Ireland and

And uh-and uh-

And the local deputy province that they can set uh

Polish group inside Scouting Ireland

Uh that they can keep identity, that they can have (.)

We can wear (.) for example (.) on our uniforms (.) Polish flag

Uh and that's (.)

[...]

It's very, very unusual

Very unusual

For every organizations that they uh let

To have uh national teams

National groups

Inside- difference nationalities inside the-

Every scout's uh organization

They have a different nationalities inside there but

They're usually

Try to uh assimilate them with uh-with uh groups

Uh what I think is good as well

Is why we choose to be a part of Scouting Ireland just to

Help our kids to assimilate

And with the- with the Irish community

This article is protected by copyright. All rights reserved. 


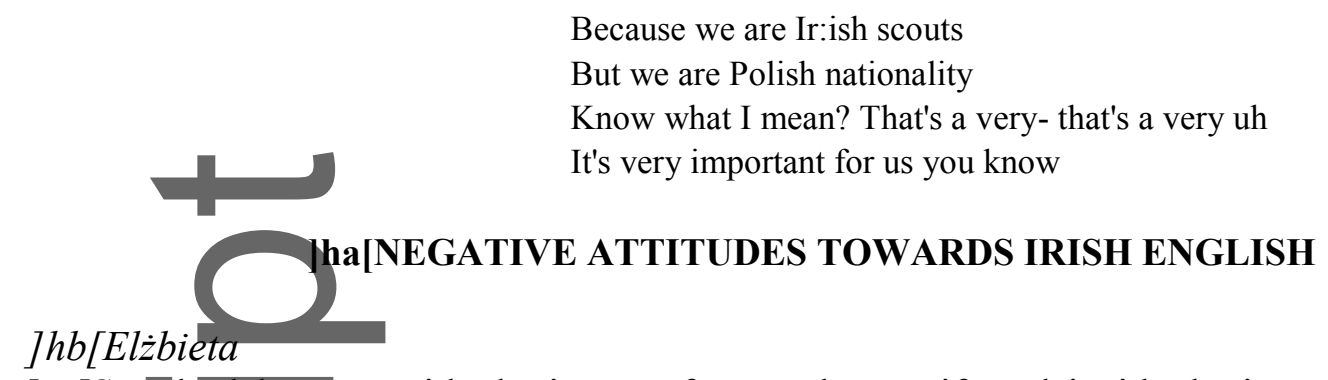

]ro[Standard language ideologies are frequently manifested in ideologies of prescriptivism and processes of avoidance. Elżbieta, a mother of three who trained as a primary school teacher in Poland, expressed a number of avoidance-targeted views of IrE. Similar to Janusz and Aleksander, she viewed IrE as marked. However, her attitude towards IrE was more anchored in notions of 'standardness' whereby she looked to BrE as the target variety. In (5) below, Elżbieta claims that IrE is 'definitely' different to the variety of English she learned in school in Poland (line 4). She reports that in school they were taught 'that posh English accent' (lines 10 11), which she also describes as 'BBC' English (line 12). In doing so, she refers to BrE implicitly, but does not explicitly use the label. She ascribes prestige to this variety, by associating it with school and instruction, and the language of mass media, which, according to Lippi-Green (1997) are both common points of reference for 'standard' languages

]p[Despite the fact that Elżbieta self-assesses her level of English highly (Table 1), she describes the difference between IrE and the English she had learned in school as 'shocking' (line 15) and reports that it took 'some time' to get used to IrE (lines 17-19). However, she goes on to report that she now pronounces 'some words' the Irish way (line 23), and that her four-year-old daughter, as one would expect, has wholeheartedly adopted IrE (lines 37-42).

(5) Elżbieta

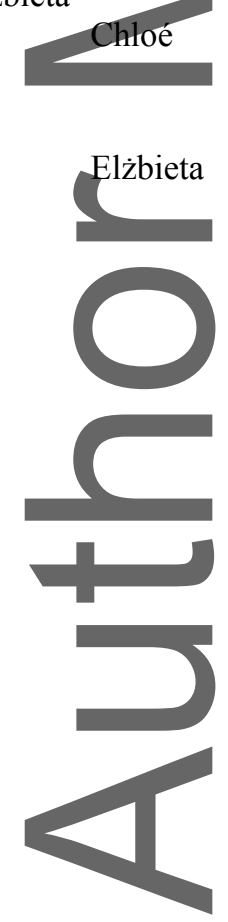

\author{
And uh when you came to Ireland did you \\ Find that uh people here (.) \\ That they spoke differently to the English you'd learned in school? \\ Mm definitely yeah \\ $(\mathrm{h})(\mathrm{h})(\mathrm{h})$ \\ Of course \\ First- first thing the accent is different \\ Because in schools they:: \\ They are teaching uh \\ It's a- uh that posh (.) uh \\ English accent (.) you know? \\ $\mathrm{BBC}$ or something \\ And it's different than:: \\ It was! \\ Uh that was shocking for me as well \\ Um:: \\ So yeah (.) it took some time \\ Then I::: \\ Get used to that accent (.) you know \\ And after some time \\ I started using the same (.) maybe not accent \\ but you know uh \\ Pronounce of some words you know \\ Like (.) it's not a "cup of tea"
}

This article is protected by copyright. All rights reserved. 


Now it's a "cup of tea" $(([\ddot{\Lambda}]))$
now you know $(\mathrm{h})(\mathrm{h})$ for me
Things like that
Like wh-what else do you
Do you think- do you find yourself saying that sounds kind of Irish?
Irish "bus" $(\mathrm{h})(\mathrm{h})(([\ddot{\Lambda}]))$
$[\ldots]$
But uh::
Um the sound you::
Like it's-it's most typical
You know that I'm changing in words
I'm trying not to say "Dublin" $(([\ddot{\Lambda}]))$ but "Dublin" $(([\mathrm{e}]))$ you know?
But I-I can hear my daughter
When uh our:
When she's reading her books if::
Like uh "up" $($.$) "mum" (([\ddot{\Lambda}]))$
You know "cup" $($.$) "bus" ().(([\ddot{\Lambda}]))$
Everything (.) it's she's ve::ry Irish now!

]fo[Elżbieta's primary example of her own and her daughter's use of IrE is her juxtaposition of two variants of the STRUT vowel, citing 'cup' (lines 24-25, 41), 'bus' (lines 30, 41), 'Dublin' (line 36) and 'mum' (line 40) as examples. The STRUT vowel (Wells 1982) in (supraregional) IrE has been described as a 'retracted and perhaps slightly rounded short vowel [... often written as $[\ddot{\Lambda}]$ where the diaresis indicates centralization of the cardinal vowel' (Hickey 2007: 328). However, in local/Northside Dublin English (Hickey 2007), which is stigmatized and associated with lower socio-economic classes, STRUT is a high rounded vowel, identical to FOOT due to the lack of the FOOT-STRUT split in local Dublin English (Hickey 2005: 228); the local/Northside pronunciation of 'Dublin' is hence [dublən] (Hickey 2005. 35). It can be presumed that Elżbieta has been exposed to both variants of Dublin English STRUT (supraregional $[\ddot{\Lambda}]$ and 'local' $[\mho]$ ) throughout her five years of living in Dublin. According to Drummond (2012) and Kobiałka (2016), the Polish pedagogical model of English draws heavily on the Southern BrE pronunciation of STRUT: a central [ $\mathrm{k}]$. Coupled with the Polish vowel system, this target is often articulated as a more open 'Polish /a/' (Drummond 2012: 7). It is likely that Elżbieta, who was educated to university level in Poland, has also been exposed to this pedagogical model, resulting in a possible conflict between her perception of the target and stigmatized variants, as well as phonological influence from her L1.

]p[Elżbieta attempts to represent how her own and her daughter's pronunciation of the STRUT vowel has changed from $[\mathrm{e}]$ to $[\ddot{\Lambda}]$ and she specifically denotes the $[\ddot{\Lambda}]$ as the vowel she is 'trying not' to produce (line 36). It comes as no surprise that she has noticed this difference in the pronunciation of the STRUT vowel, as there is an evident discrepancy between the DubFin $[\ddot{\Lambda}]$ and $[\mho]$ compared to the prestigious British standard $[\mathrm{e}]$ to which she had previously been exposed. To make her point clear, Elżbieta exaggerates the STRUT

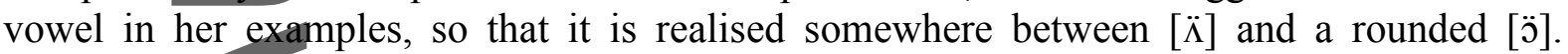
Through this juxtaposition of two variants of an English vowel set - one a stigmatized, local, IrE variant and the other the prestigious BrE variant - she expresses a negative and avoidance-targeted attitude towards IrE.

This article is protected by copyright. All rights reserved. 


\section{]hb[Michat}

]fo[Michał, a project manager, had been living in Dublin for seven years at the time of interview. In (6) below, he, similarly to Elżbieta, finds IrE to occupy a marked status and was initially 'shocked' by his first encounter with the variety (line 14). He describes the pronunciation of IrE as 'so different' (line 12) and goes so far as to question the label of 'English' as appropriate for IrE: 'come on, is this English or is it something else?' (line 15). He thus calls into question the legitimacy of IrE as a variety, compared to what he perceives 'English' to be.]de[

(6) Michał

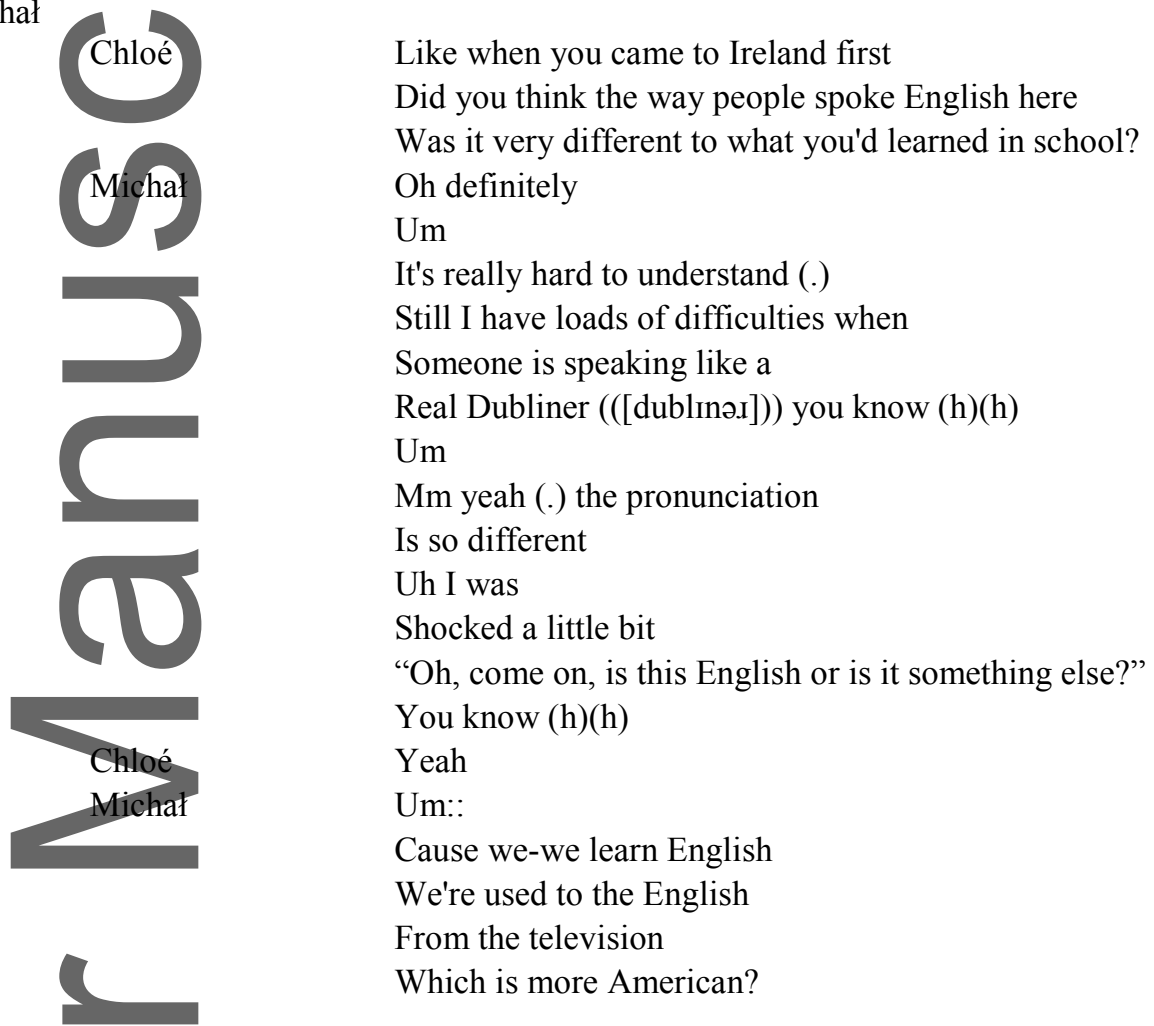

Like when you came to Ireland first

Did you think the way people spoke English here

Was it very different to what you'd learned in school?

Oh definitely

Um

It's really hard to understand (.)

Still I have loads of difficulties when

Someone is speaking like a

Real Dubliner (([dublinər] $])$ you know (h)(h)

Um

Mm yeah (.) the pronunciation

different

Shocked a little bit

"Oh, come on, is this English or is it something else?"

ow (h)(h)

Um:

Cause we-we learn English

We're used to the English

Which is more American?

]fo[Michat speeifically compares IrE with AmE, which he claims has been the primary source of his English language input, due to its predominance in television (lines 20-22). He refers to himself as a member of a group: 'we' (lines 19-20). In so doing, he marks his affiliation with other Poles who have learnt (American) English. He implies that learning English in Poland is a homogenous pedagogical experience, where 'they' learn English from television

]p[Furthermore, similarly to Elżbieta, Michał has noticed that the STRUT vowel is a marked feature of Dublin English and differs from the Polish pedagogical model of this vowel. However, his comparison is subtler than that of Elżbieta. Rather than providing a list of examples, he simply states that when he speaks with 'a real Dubliner' (line 9), he has difficulty understanding them. In an act of performance, he pronounces 'Dubliner' as [dublinəI]. Since this pronunciation differs from how he has been pronouncing 'Dublin' until and after this point, he creates a juxtaposition, further compounding his view of 'us' versus 'them'. He clearly denotes that this is how Dubliners refer to themselves and not how he, Michał, would do so.

In (7) below, he denotes IrE as indexical of Irish nationality by stating that it is 'your culture' (line 12) and 'you can recognize your nationality that way' (line 21). When asked

This article is protected by copyright. All rights reserved. 
whether IrE may be viewed as a valuable resource, a 'good thing' (line 1), he states that it may be, but on the condition that it not be 'too strong' (line 4), otherwise it may not be understood. It is clear that Michał views IrE as highly marked, and not particularly desirable.]de[

(7) Michał

And do you think it's a good thing to have an Irish accent?

Like say: internationally?

Um:::
If it's not too strong (.) yeah why not?
Well but I::
I know that there's some different people
Uh who are different nationalities
Who also have difficulties understanding that
So uh:
[Yeah
Um
Yeah but it's also your-your culture
So::
[Yeah
Uh::
When you hear-when you hear someone speaking Irish
Uhichat in a different country
You know that it's Irish (.) right?
Mm-hm
Shloé uh:
You can recognize your nationality that way
Yichał
Yoeah that's true

\title{
Tha|AMBIVALENT ATTITUDES TOWARDS IRISH ENGLISH
}

\section{]hb[Beata}

]ro[Beata had been living in Ireland for four years at the time of interview. When prompted about her views towards IrE when she first arrived in (8) below, she was more inclined to comment on the speed with which people spoke (lines 23,32 ) rather than the accent variety with which they spoke. Nonetheless, she alludes to AmE as having been her primary source of naturalistic input prior to arrival in Ireland, since her formal education experience was so limited (lines 10-14). However, in comparison to Michał, she does not compare AmE and $\mathrm{IrE}$, and it is clear that her primary experiences in Ireland were clouded by her overall lack of comprehension (lines 8 and 32), rather than motivated by any particular language ideology. With any evaluation of an L2, there is an element of general unfamiliarity with a language, which must be interpreted separately from unfamiliarity with a particular variety of that language (Abercrombie 1967). Beata appeared to be relatively unaware of the existence of IrE as a variety, and did not perceive English in Ireland to be any more different than the English she had encountered elsewhere.]de[

(8) Beata

\author{
When I was you know with the Irish family at the- \\ [...] \\ You had every time- every evening \\ The dinner together
}

This article is protected by copyright. All rights reserved. 


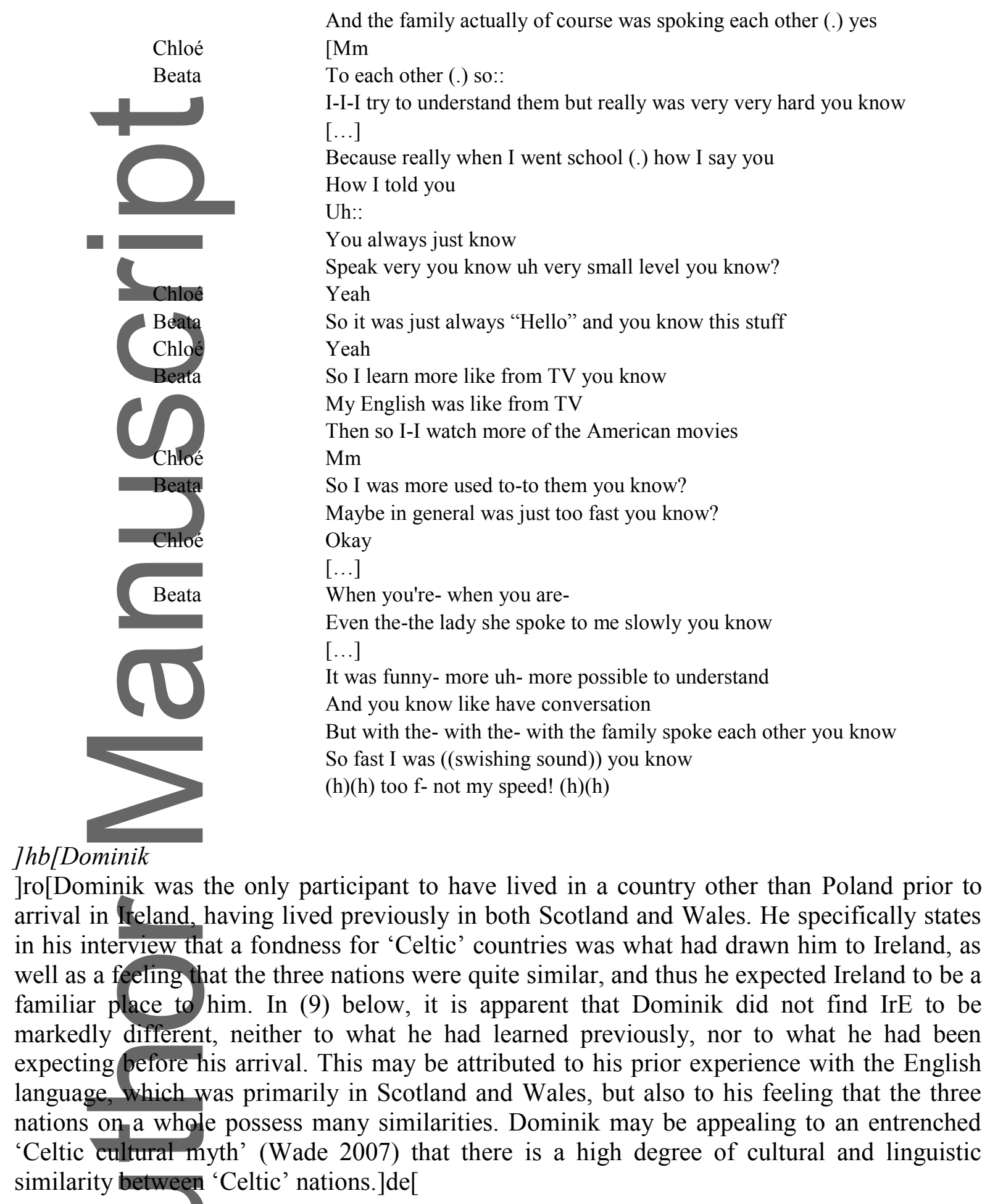

(9) Dominik (email correspondence) ${ }^{5}$

This Irish version doesn't differ much from the one I knew (i.e. being in Scotland or Wales); maybe
just a bit different accent and some slang/every day words like "grand", "u're all right?" [sic] - for
friend welcoming. Some words like these are so often repeating every day in conversations with Irish
people that some words are easier to find in my memory than the others.

]fo[In (9) Dominik also cites lexical items as examples of the idiosyncratic nature of IrE: 'grand' and 'you're all right?'. Aleksander, in (3) above, also cites the word 'grand' as a

This article is protected by copyright. All rights reserved. 
salient feature of IrE (line 55). Dominik explains that these lexical items or formulaic sequences (Wray 2000) are of particular salience to him as they are repeated on a daily basis and thus easily retrievable from memory. He views these as the main differences between IrE and 'the one [variety] I knew', which he explains is Scottish and Welsh English. Otherwise, he views IrE neither as particularly marked, nor as particularly undesirable.

\section{ThafDISCUSSION: LANGUAGE, IDENTITY AND IDEOLOGY}

]ro[By analysing the metalinguistic discourse that emerged in sociolinguistic interviews, this article has-diseussed the language attitudes of six new arrivals from Poland towards IrE, as well as their donstruction of identity through language, and some of their beliefs about different varieties of world Englishes. While more concrete, quantifiable attitudes could have been obtained from a survey-style investigation, this method aimed to target participants' views that were implicit, as well as explicit, in their discourse. The participants most likely to possess positive views were those who had invested in a new identity in Ireland. For Janusz, this was his identity as a successful young professional conducting business transactions around Ireland; for Aleksander, it was his dual identity as a Polish-Irish scout leader. In this sense, they follow Norton (2000) that migrants who 'invest' in their new identities by creating 'opportunities to speak' are more likely to acquire the language (or variety) of the new community in which they find themselves. The participants expressing more negative views towards $\mathrm{IrE}$ were more likely to evaluate $\mathrm{IrE}$ in relation to other Inner Circle varieties such as BrE and AmE. In the case of Elżbieta, she implies that she considers BrE to be the norm for 'standard' English, by connecting it to the language of her schooling and of the mass media (BBC). She makes conscious efforts to avoid what she perceives as typically Irish phonological features and aims to continue to use realizations that are closer to the Polish pedagogical norms (Drummond 2012; Kobiałka 2016). Michał explicitly cites AmE as having been his primary source of English input prior to arrival in Ireland and says that that is what he is 'used to'. He recognises the importance of IrE as an integral part of Irish identity, but he clearly sets himself apart from the Irish and in so doing, also distances himself from using IrE. Both reported experiences of shock upon first encountering $\mathrm{IrE}$, and that it took a considerable length of time to grow accustomed to it. The fact that the new arrivals with more ambivalent attitudes towards IrE were also those with a lower level of proficiency in English and a shorter length of residence in Ireland, is of note. Particularly in the case of Beata, she did not distinguish between her difficulty with the English language per se and her difficulty with IrE. She explained her lack of comprehension of IrE speakers by the fact that she had had limited prior schooling in English. In comparison, the participants with negative attitudes, who had a higher level of English and had had university-level schooling (which included English), reported the same feelings of miscomprehension as Beata, but attributed them to the dissonance between IrE and their perceived 'norm', rather than their own shortcomings

]p[Taking the approach of Bourdieu (1991), it could be said that while the negative attitude migrants had a eertain level of linguistic 'capital' in English before arriving, they found themselves unable to transfer it to their new environment and felt as though they were 'back to square one'. It could be said that Beata, on the other hand, acquired the major part of her linguistic capital in Ireland. For her, IrE is the benchmark, and the unmarked, default form, arguably because this was her first encounter with continuous amounts of naturalistic English language input in a wide variety of communicative contexts. Dominik's experience was different, in that he already had a positive outlook towards varieties not commonly perceived as the 'norm' in pedagogical settings in the Expanding Circle, and he also felt a unity

This article is protected by copyright. All rights reserved. 
between the 'Celtic' nations and hence the 'Celtic' Englishes. This shows how one ideology - concerning nations, nationhood and shared cultural values - may be transferred to ideologies of language.

In light of a markedness continuum or 'hierarchical structuring of difference' (Bucholtz \& Hall 2004: 372), it could be said that the migrants' views of world Englishes were situated along both a cline of markedness, or the degree to which the variety appeared different as compared to an abstract benchmark of 'English', and desirability. For those with a positive attitude, IrE was marked, but not in direct comparison to any perceived 'norm' or 'standard', and for Janusz, for example, it functioned as a valuable communicative tool. For those with a negative attitude, IrE was not viewed as a homogenous entity, but as a variety possessing socioeconomically-stratified localized varieties. This is a crucial difference between this grouping and the others. The fact that they juxtaposed supraregional forms of IrE (Hickey 2007: 309-315) with 'local' forms showed their awareness of the stigma surrounding certain varieties of IrE/Dublin English. This, coupled with 'standard language' ideologies that tended to view $\mathrm{BrE}$ and $\mathrm{AmE}$ as the norm providers, resulted in them viewing IrE as both highly marked and highly undesirable. Finally, for the ambivalent participants, IrE was not viewed as particularly marked; rather, it represented the English language as a whole.

\section{]ha[CONCLUSION}

]ro[In this article we have aimed to show that migrants are sensitive to variability in IrE and evaluate varieties according to various criteria, such as degree of accentedness or difficulty of comprehension. However, the degree to which these evaluations are made, and the extent to which they influence the language one uses, appear to be influenced by language ideologies pertaining to 'standardness' and 'correctness', as well as other factors, that may vary from speaker to speaker. Individual differences in migrants' perceptions of IrE were also observed by Migge (2012: 325): 'Attitudes towards varieties of IrE are diverse depending on a variety of factors such as national background, attitudes to variation and other varieties of English and their-speakers'. It is this relationship between an individual's attitude to language on a micro level 'from below', and how these attitudes relate to ideologies on a broader, macro level 'from above', that this article has aimed to expose. Language, both in terms of language choice and language use, can be a powerful tool in the construction and maintenance of identity. The participants discussed in this article all make use of their linguistic repertoires to perform acts of identity, or to adopt a 'language identity': 'the assumed and/or attributed relationship betyeen one's sense of self and a means of communication which might be known as a language [or] a dialect' (Block 2006: 35-36). For Aleksander, for example, this identity is that of migrant community leader, and that of active Irish citizen. This duality is the kind of hybridity experienced by contemporary migrants, who move fluidly across boundaries, adopting varying degrees of embeddedness within social fields (Levitt \& Jaworsky 2007: 130). Thus while language is 'the most flexible and pervasive [...] among the many symbolic resources available for the cultural production of identity' (Bucholtz \& Hall 2004: 369), its correlation with identity is not fixed, static or predictable; on the contrary, it is complex, emergent, fluid and situated, and particularly subject to change in the context of migration.

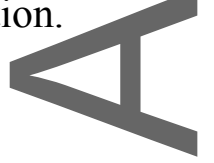

\section{]ha[ACKNOWLEDGEMENT}

]ro[The research presented in this article was made possible by a Government of Ireland Postgraduate Scholarship awarded to the first author from the Irish Research Council.

This article is protected by copyright. All rights reserved. 


\section{]ha[NOTES]n[}

1. 'British English' in this article refers to the English spoken in England. It does not refer to the English spoken in Wales or Scotland.

2. The Common European Framework of Reference for Language (CEFR) is a tool widely used for self-assessment of language proficiency, where learners indicate their levels of agreement with statements about their language proficiency across four key areas: listening, speaking, reading and writing (Council of Europe 2001). The highest level is $\mathrm{C} 2$, followed by (in descending order of proficiency) $\mathrm{C} 1, \mathrm{~B} 2, \mathrm{~B} 1, \mathrm{~A} 2$ and A1.

3. Transcription eonvention based on Goodwin (1990) and Pichler (2013):

\begin{tabular}{|l|l|}
\hline$!$ & Animated or emphatic tone \\
\hline[ & Backchannel (overlapping) \\
\hline$(\mathrm{h}),(\mathrm{h})(\mathrm{h}),(\mathrm{h})(\mathrm{h})(\mathrm{h})$ & Breathiness, laughter \\
\hline$((\mathrm{text}))$ & Extralinguistic information \\
\hline- & False start; sudden cut-off of current sound \\
\hline “ & Quoted speech \\
\hline$?$ & Rising intonation contour \\
\hline$[\ldots]$ & Section of transcription removed \\
\hline$(),.(.)$. & Short, medium pause \\
\hline$:,::$ & Syllable lengthening \\
\hline
\end{tabular}

4. Galway is approximately $200 \mathrm{~km}$ west, and Portlaoise about $95 \mathrm{~km}$ south-west, of Dublin.

5. Dominik was interviewed in the same way as the other participants discussed in this article (see section 'DATA COLLECTION AND METHODOLOGY'). However, he later followed up by emailing the first author with some more detailed answers to the questions she had posed in the interview, stating that he preferred to answer certain questions after having thought them over.

\section{]ha[REFERENCES}

]ref[Abercrombie, David. 1967. Elements of general phonetics. Edinburgh: Edinburgh University Press.

Bayley, Robert \& Vera Regan. 2004. Introduction: The acquisition of sociolinguistic competence. Journal of Sociolinguistics 8(3). 323-338.

Bhabha, Homi. 2004. The location of culture. London: Routledge.

Block, David. 2006. Multilingual identities in a global city. Basingstoke: Palgrave Macmiltan.

Bolton, Kingsley. 2003. Chinese Englishes: A sociolinguistic history. Cambridge: Cambridge University Press.

Bourdieu, Pierre. 1991. Language and Symbolic Power. Cambridge: Polity Press.

Bucholtz, Mary \& Kira Hall. 2004. Language and identity. In Alessandro Duranti (ed.), A companion to linguistic anthropology, 369-394. Malden, MA: Blackwell.

Central Statisties Office. 2012. Profile 6: Migration and diversity. Dublin: Stationery Office.

Council of Europe. 2001. Common European framework of reference for languages: Learning, teaching, assessment. Strasbourg: Language Policy Unit.

Coupland, Nikolas \& Hywel Bishop. 2007. Ideologised values for British accents. Journal of Sociolinguistics 11(1). 74-93.

de Costa, Peter. 2011. Using language ideology and positioning to broaden the S.L.A. learner beliefs landscape: The case of an ESL learner from China. System 39(3). 347-358.

This article is protected by copyright. All rights reserved. 
de Swaan, Abram. 2010. Language systems. In Nikolas Coupland (ed.), The handbook of language and globalization, 56-76. Malden, MA: Blackwell.

Diskin, Chloé. 2016. Standard language ideologies in multicultural Ireland: A case study of Polish and Chinese migrants in Dublin. In Vera Regan, Chloé Diskin \& Jennifer Martyn (eds.), Language, identity and migration: Voices from transnational speakers and communities, 287-326. Oxford: Peter Lang.

Diskin, Chloé \& Vera Regan. 2015. Migratory experience and second language acquisition among Polish and Chinese migrants in Dublin, Ireland. In Fanny Forsberg Lundell \& Inge Bartning (eds.), Cultural migrants and optimal language acquisition, 137-177. Bristol: Multilingual Matters.

Drummond, Rob 2012. The Manchester Polish STRUT: Dialect acquisition in a second language. Journal of English Linguistics 41(1). 65-93.

Eckman, Fred R. 1977. Markedness and the contrastive analysis hypothesis. Language Learning 27(••). 315-330.

Goodwin, Marjorie Harness. 1990. He-said-she-said: Talk as social organization among black children. Bloomington, IN: Indiana University Press.

Hickey, Raymond. 2005. Dublin English: Evolution and change. Amsterdam: John Benjamins.

Hickey, Raymond. 2007. Irish English: History and present-day forms. Cambridge: Cambridge University Press.

Hickey, Raymond. 2012. Standard Irish English. In Raymond Hickey (ed.), Standards of English: Codified varieties around the world, 96-116. Cambridge: Cambridge University Press.

Irvine, Judith 1989. When talk isn't cheap: Language and political economy. American Ethnologist 16(・•). 248-267.

Jaffe, Alexandra. 2009. The production and reproduction of language ideologies in practice. In Nikolas Coupland \& Adam Jaworski (eds.), The new sociolinguistics reader, 390-404. London: Palgrave Macmillan.

Kachru, Braj B. 1985. Standards, codification and sociolinguistic realism: The English language in the outer circle. In Randolph Quirk \& Henry G. Widdowson (eds.), English in the world: Teaching and learning the language and literatures, 11-30. Cambridge: Cambridge University Press.

Kobiałka, Ewa. 2016. Language, identity and social class among Polish migrants in Ireland. In Vera Regan, Chloé Diskin \& Jennifer Martyn (eds.), Language, identity and migration: Voices from transnational speakers and communities, 191-216. Oxford: Peter Lang.

Labov, William. 1972. Language in the Inner City: Studies in the Black English Vernacular. Philadelphia, PA: University of Pennsylvania Press.

Levitt, Peggy \& Nadya B. Jaworsky. 2007. Transnational migration studies: Past developments and future trends. Annual Review of Sociology 33. 129-156.

Lippi-Green, Rosina. 1994. Standard language ideology, and discriminatory pretext in the courts. Language in Society 23(2). 163-198.

Lippi-Green, Rosina. 1997. English with an accent: Language, ideology and discrimination in the United States. London: Routledge.

Matsuda, Aya \& Paul Kei Matsuda. 2010. World Englishes and the teaching of writing. TESOL Quarterly 44(2). 369-374.

Migge, Bettina. 2012. Irish English and recent immigrants to Ireland. In Bettina Migge \& Máire Ní Chiosáin (eds.), New perspectives on Irish English, 311-326. Amsterdam: John Benjamins.

This article is protected by copyright. All rights reserved. 
Noack, Rick \& Lazaro Gamio. 2015. The world's languages, in 7 maps and charts. The Washington Post. (23 April, 2015.)

Norton, Bonny. 2000. Identity and language learning: Gender, ethnicity and educational change. Harlow: Longman.

Pichler, Heike. 2013. The structure of discourse-pragmatic variation. Amsterdam: John Benjamins.

Seargeant, Philip. 2009. Language ideology, language theory, and the regulation of linguistic behaviour. Language Sciences 31(4). 345-359.

Wade, Nicholas. 2007. English, Irish, Scots: They're all one, genes suggest. The New York Times. (5 March, 2007.)

Wells, John C. 1982. Accents of English. 3 vols. Cambridge: Cambridge University Press.

Widdowson, Henry G. 1994. The ownership of English. TESOL Quarterly 28(2). 377-389.

Wray, Alison. 2000. Formulaic sequences in second language teaching: Principle and practice. Applied Linguistics 21(••). 463-489.

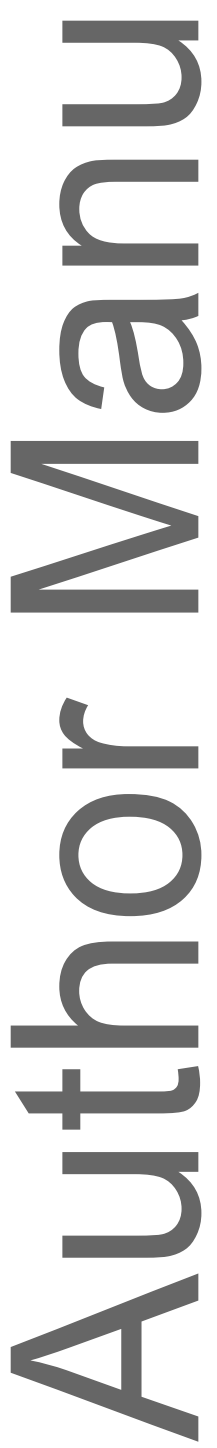

(Received 8 July 2016)

This article is protected by copyright. All rights reserved. 


\section{University Library}

\section{- M M N E R VA A gateway to Melbourne's research publications}

Minerva Access is the Institutional Repository of The University of Melbourne

Author/s:

Diskin, C;Regan, $V$

Title:

The attitudes of recently-arrived Polish migrants to Irish English

Date:

2017-06-01

Citation:

Diskin, C. \& Regan, V. (2017). The attitudes of recently-arrived Polish migrants to Irish

English. World Englishes: journal of English as an international and intranational language, 36 (2), pp.191-207. https://doi.org/10.1111/weng.12253.

Persistent Link:

http://hdl.handle.net/11343/292979 